\title{
Study and evaluation the Marshes and surrounding areas in south of Iraq.
}

\author{
HusamAl-Nussairi ${ }^{1}$, and Khalida Hassan ${ }^{2}$ \\ 1 State University of Land use planning, Moscow 105064, Russia \\ 2 College of Agriculture and Forestry, Duhok University, Duhok 42001, Kurdistan Region, Iraq
}

\begin{abstract}
In this study, the marshlands in southern Iraq were investigated, focusing on the Hawizeh Marshlands and adjacent areas, by studying the scenario and quantities of water, in addition to the hydraulic and hydrochemical characteristics. To accomplish the objects of this study the researcher visited some fields, made interview with farmers, specialists, authorities and directorates related to this study. The results of this study indicate that there are a huge problem existed in the drainage systems with absence of natural outlets, the discharges of drainage water is towards Al- Hawizeh marsh which flow back its water into Tigris river through several canals, increasing salinity, scare of water, miss-use of land, lack of governments efforts to promote agricultural production leads to loss of soil productivity and land degradation.
\end{abstract}

\section{Introduction}

As their name suggests, the Mesopotamian Marshes are located in the larger region which used to be called Mesopotamia. The marshes lie mostly within southern Iraq and a portion of southwestern Iran. Originally covering an area of $20,000 \mathrm{~km} 2(7,700 \mathrm{sq} \mathrm{mi})$ and divided into three major areas, the Central Marshes lie between the Tigris and Euphrates, while the Hammar Marshes lie south of the Euphrates and the Hawizeh Marshes are bound east of the Tigris. Before the 2003 Invasion of Iraq, about $90 \%$ of the marshes had been drained.

The marshes lie on a flat alluvial plain, as the Euphrates decreases only $12 \mathrm{~m}$ (39 ft) in elevation during its last $300 \mathrm{~km}(190 \mathrm{mi})$ while the Tigris falls $24 \mathrm{~m}(79 \mathrm{ft})$. This delta provides an environment that allows the Tigris and Euphrates to meander, forming distributaries. The Euphrates has often terminated near Nasiriyah into the Hammar Marshes as its flow slows. The Tigris can distribute some of its flow into the Central and Hawizeh marshes as it slows near Amarah. Downstream of Amarah though, several of its tributaries originating in Iran allow the Tigris' flow to increase and maintain a steady course thereafter. The three marshes combined once provided an intertwined environment, particularly during periods of flooding as the rivers overflowed.[2] Al-Hawizeh is the largest marsh located between latitudes (31 $46^{\prime} 54.80^{\prime \prime}$ - 31 $\left.02^{\prime} 39.90^{\prime \prime}\right)$ north and longitudes (47051'19.90" $\left.-47^{\circ} 31^{\prime} 23.30^{\prime \prime}\right)$ east, and extends between the Iraqi-Iranian borders. The largest area of this marsh located in the Iraqi side and extends from south of $\mathrm{Al}$ Musharrah district in Maysan province to Qurna town in Basrah province, with total length of (80) $\mathrm{km}$ and (30) km width. Al-Hawizeh a marsh joined
Al-Sanaaf marsh from the north. There are also another marshes extend into the northern parts like Al-Hushaya marsh. All marshes receive their waters from AlMusharrah, Al-kahlaa and Al-Majreeh streams, as well as the rivers descending from the highlands of Iran such as Al-Teeb, Karkhah and Dwiridj. There is no exact estimation for the area of Al-Hawizeh marsh, because the area change from one season to another and from one year to another due to varying amounts of water that reach the area from various sources such as floods and rain. It have been estimated to about (2500 - 3000) $\mathrm{km} 2$ in the flood season and shrinks a lot during the Chihod season (dry) to become less than half the area above according to (General Commission of ground water). The area inside Iraq is about (1350) $\mathrm{km} 2,80 \%$ of this area lies within the province of Maysan according to (Agriculture Directorate of Maysan, department of marshes recovery).

The extensive area covered by marshes, especially in flood seasons affects effectively the groundwater depth and capillary movement which under dry conditions lead to soil salinization. The existence of water on the surface soil for long periods leads to water logging which cause leaching in good drainage soil and reduce the degree of salinization. The existence of water in bad drainage soils left pools of water which cause salt accumulation on the soil surface due to high evaporation in hot season [3].

The drying process during (Iraq-Iran) war reduced the area of marshes from $15000-20000 \mathrm{~km} 2$ to less than $2000 \mathrm{~km} 2$ in 2003. The Central and Al-Hamar Marshes vanished by $97 \%$ and turned to land covered with salt crust, while only $1 / 3$ part of Al-Hawizeh marsh area existed for military reasons according to (Marine 
Science Center in University of Basrah). Al-Kahlaa River and its branches discharged their water into the marshes and swamps in the eastern and north east of AlKahlaa city. The marsh and swamps soil is clayey in nature and is likely to be poorly drained as well. They are continually flooded and covered dominantly with cattails and hydrophytic plants.

\section{Flooding marshlands in Maysan province}

Before 1973, Al-Hawizeh marsh covers an area of 1800 $\mathrm{km} 2$ (table 1), in eighties and nineties of the last century the area was reduced (figure 1). After 2003, the rehabilitation of marshes began but not as required because of the scarcity of water in Tigris river and its branches.

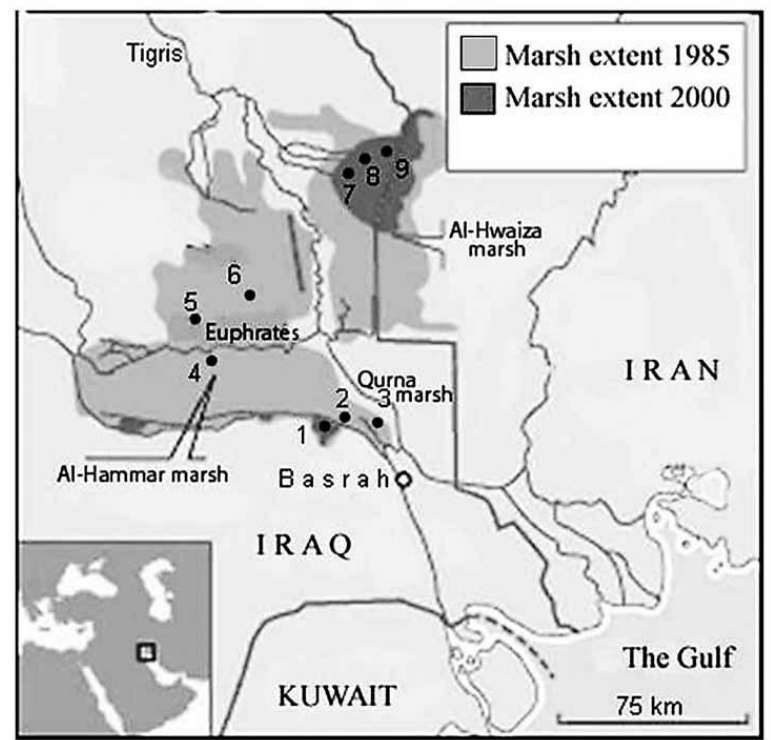

Figure (1) Difference of marshes extent in 1985 and 2000, source (http://www.afka.org).
From (table 1) the rate of flooding percentage of AlHawizeh marsh land in 2008 accounted for $78 \%$ of the total area $(1055 \mathrm{~km} 2)$ eligible for flooding, and decreased in July 2010 to $62 \%$.

For central marshes land, the rate of flooding percentage was 6\% in 2008 and increased to $13 \%$ in July 2010 (Marshes Recovery Center in Maysan). In general, the unflooded area exposed to drought and turned to barren land covered with salt crust.

Multi-scenarios program was found in order to restoring and re-flooding southern Iraqi marshes, through a conceptual hydrological model depending on wetlands water balance equation in order to predict the incoming water discharge from Tigris-Euphrates river system.

Table (1) Rate of flooding of marshes within Maysan province. (Cited from Center of Marshes Recovery in Maysan).

\begin{tabular}{|c|c|c|c|c|c|c|c|}
\hline \multirow[b]{2}{*}{ Marsh } & \multirow[b]{2}{*}{$\begin{array}{c}\text { Area be- } \\
\text { fore } \\
\text { drought in } \\
1973 \mathrm{~km}^{2}\end{array}$} & \multicolumn{3}{|c|}{ Area after revival $\mathrm{km}^{2}$} & \multirow[b]{2}{*}{$\begin{array}{c}\text { Area eligible } \\
\text { for flooding } \\
\mathbf{k m}^{2}\end{array}$} & \multirow[b]{2}{*}{$\begin{array}{c}\text { Rate of } \\
\text { flooding \% }\end{array}$} & \multirow[b]{2}{*}{ year } \\
\hline & & $\begin{array}{c}\text { Area ex- } \\
\text { cluded } \\
\text { from the } \\
\text { flooding } \\
/ \mathrm{km}^{2}\end{array}$ & $\begin{array}{c}\text { Non- } \\
\text { flooded } \\
\text { area } \\
/ \mathbf{k m}^{2}\end{array}$ & $\begin{array}{c}\text { Flooded } \\
\text { area } / \mathbf{k m}^{2}\end{array}$ & & & \\
\hline \multirow{3}{*}{$\begin{array}{c}\text { Al Hawaiza } \\
\text { marsh }\end{array}$} & 1800 & 745 & 232 & 823 & 1055 & 78 & 2008 \\
\hline & 1800 & 745 & 338 & 717 & 1055 & 68 & 2009 \\
\hline & 1800 & 745 & 401 & 654 & 1055 & 62 & 2010 \\
\hline \multirow{3}{*}{$\begin{array}{l}\text { Central } \\
\text { marshes }\end{array}$} & 1450 & 222 & 1155 & 73 & 1228 & 6 & 2008 \\
\hline & 1450 & 222 & 1155 & 73 & 1228 & 6 & 2009 \\
\hline & 1450 & 222 & 1069 & 159 & 1228 & 13 & 2010 \\
\hline
\end{tabular}


The restoring processes use the following scenarios depending on physical nature of southern Iraqi marshlands, vegetation cover, water quality and quantity and water consumptive use for urban and rural uses (http://www.uobasrah.edu.iq):

1. Re-flooding $100 \%, 75 \%, 50 \%$ and $25 \%$ of formal marshland area on coexistence of high water discharge.

2. Re-flooding $100 \%, 75 \%, 50 \%$ and $25 \%$ of formal marshland area on coexistence of current water discharge.

3. Re-flooding $100 \%, 75 \%, 50 \%$ and $25 \%$ of formal marshland area on coexistence of low water discharge.

Depending on the type of the vegetated crop, wheatbarley-rice group and wheat-barley group, all the above scenarios were subjected to sub-scenario. From the results of water balance equation, another main scenario was obtained to calculate a salt balance of southern Iraqi marshlands, taking into account the re-flooding temporal schedule. The results indicated that because of shortage in incoming water supplies ranging between (30-227), (4-32) and (74-209) $\mathrm{m} 3 / \mathrm{sec}$ in Al-Hammar, Al-Qurnah, and Al-Hawizeh marshes on low and high water respectively, it is impossible recover the whole former area of south Iraqi marshlands.

The scenario was failed when it was used in attempting to restoring $75 \%$ of Al- Hammar and Al-Hawizeh marshland former area. It was also failed when it is used to restore Al-Qurnah marshes on cultivating wheatbarley-rice crop group, but it attains some success when cultivating wheat-barley crop group. The scenario of restoring $50 \%$ of Al-Hammar and Al-Hawizeh marshland former area was failed, in spite of the 30\% increase for incoming water supplies of current discharge. By applying water and salt balances, the scenario appears to be valid on resorting Al-Qurnah marshland although suspicion could be appears on continuity of high water discharge from the upper Tigris - Euphrates drainage basin, bearing in mined the future increasing in rural and urban water uses.

Due to overshooting restoration time period and increasing in dissolved solid concentration, $25 \%$ of former southern Iraqi marshes area restoring scenario was failed. Despite there are surplus water discharge of about 19-103, 158-265 and 91-250 m3/sec in Al- Hawaiza marshlands, Al-Qurna and Al-Hammar marshlands.

The achievement of recovery plan applied by the center marsh under the supervision of the ministry of water resources is about 20 thousand square kilometers, amounting to $20 \%$ of the total area of marshes, and according to ministry of water resources, the plan designed to revive the marshes will take 5 years.

\section{Al - Hawizeh marsh Scenario}

As a result of topography, the area from Al-Kahlaa area, specifically at the point where the river branched is described by slight slope with $9 \mathrm{~m}$ above sea level decreasing to $6 \mathrm{~m}$ at the point where the branches joined Al- Hawizeh marsh. In Iranian side the slop is $13 \mathrm{~m}$ above sea level at Karkheh River and decreased to 6.5 $\mathrm{m}$ at Al- Hawizeh marsh (figure 2). Iranian dike at the border decrease water flow by $20 \%$ in Iraq marshes (Ministry of water resources).

\section{Hydraulic characteristics of the marshes area}

Generally the local aquifers were open to all the marshland, as a result the water flow from high pressures hydraulic area to low pressures areas, depending on the topography the water move from Paleozoic deposition in the north-east of Maysan province, (where is the presence of Hamrin mountains series) towards the marshes (General Commission of ground water) (figure 3 ). The water also moves from wet to dry area, therefore the surround areas as Al- 
Kahlaa area also affected by such movement.

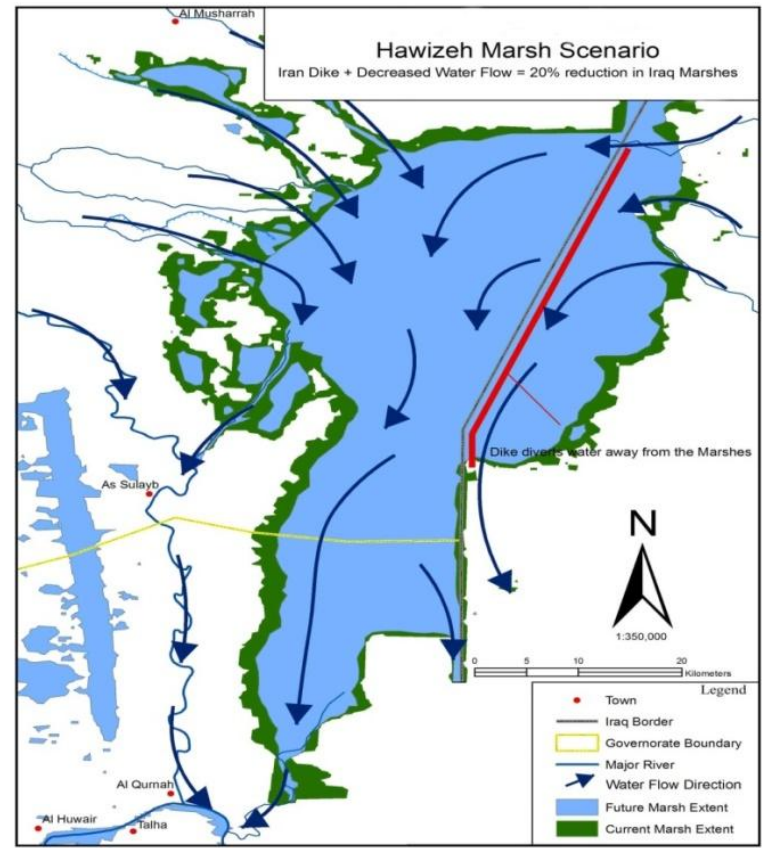

Figure (2) Al Hawizeh marsh scenario (cited from directorate of agriculture in Maysan).

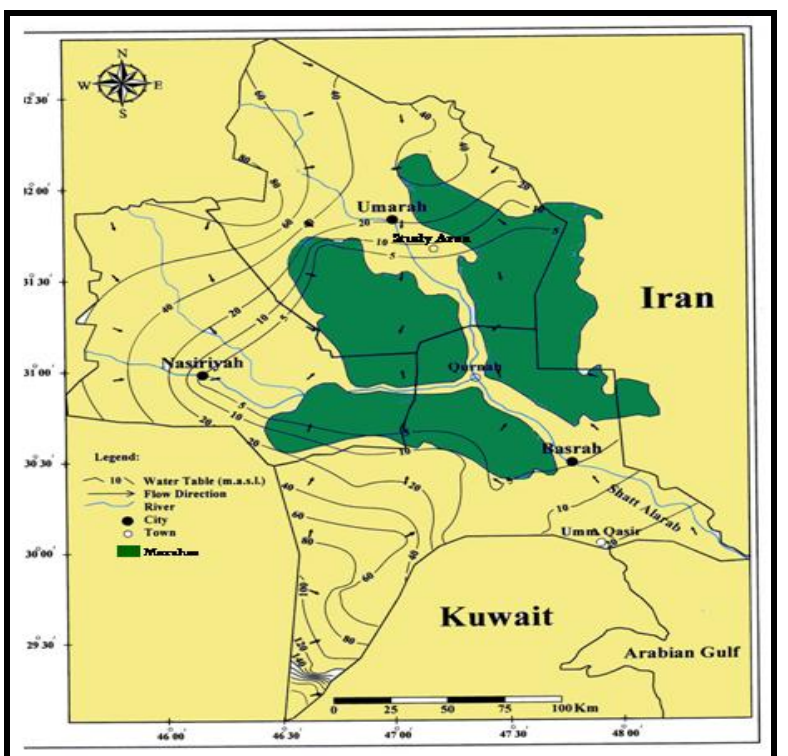

Figure (3) Map for levels of groundwater and directions of their movement in marshes regions, (cited from General Commission of ground water).

\section{Hydrochemical characteristics of groundwater in marshlands:}

As previously referred the sub surface movement of groundwater is toward the Central Marsh which then settles under shallow depths. Because of the long distance and the movement of groundwater toward the discharge area and the lack of natural recharge from rainfall, the salt concentrations in water is expected to be high and not suitable for agricultural, human, animal and even industrial purposes. (Figure 4) represents a map for the concentration of dissolved salts in the groundwater. The general concentration was very high and reached (65000) ppm in the Central Marshes, and for Al-kahlaa region it is limited between (4500055000) ppm. It is clear from this map that the salt concentrations in Al-Hawizeh marsh increase towards the west because of the presence of border rivers feeding the lagoon from the Iranian side which had an important role in reducing the concentrations of salt. According to (FAO 1985), the water is not suitable for agricultural purposes because it exceed the limit (2000 ppm).

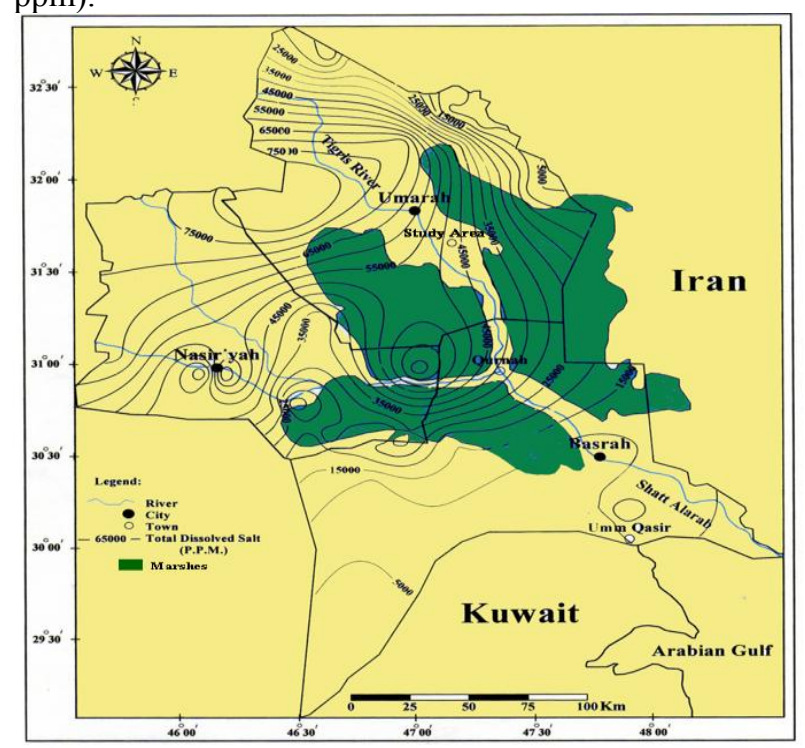

Figure (4) Map for concentration of total dissolved salts in ground water in marshes regions, (cited from General Commission of ground water).

\section{Types and texture of soil}

The soils are formed as a result of irrigation water deposits and sedimentation has been longley determined by the subsequent irrigation systems. Levee and flood plain soil are found. A striking feature is the very high content of calcium carbonate $25-30 \%$ is quite common and less than $20 \%$ is rare. As may be expected under prevailing climatic conditions, the organic content is low to very low and the texture is clay loam. The study area includes:

\section{River levees soil:}

These deposits extend as narrow strips along both side of Al-Kahlaa River and its branches (figure 5). According to previous studies in the area [4], the soil is medium textured (silty loam) and usually located at higher elevation (1.5-2.0 m) than flood plain. These soils characterized by good drainage, and low salinity level 1-8 ds.m-1 [1].

\section{Flood plain soil:}

The rushing water of Al-Kahlaa River tends to sort the sediment particles by size. First dropping the gravel and coarse materials then depositing the finer material towards the bottom of the alluvial fan ending in marshes and swamps. These soils characterized by high percen- 
tage of silt and clay, silty clay loam texture and low to

moderate

permeability

[4], (table

2)

Table (2) Types and texture of soils in study area, source [4].

\begin{tabular}{|c|c|c|c|c|c|}
\hline \multirow{2}{*}{ Types of soil } & Characteristics \% & \multicolumn{3}{|c|}{ Depths / (cm) } & \multirow{2}{*}{$\begin{array}{c}\text { Texture for all } \\
\text { depths }\end{array}$} \\
\cline { 2 - 5 } & & $0-30$ & $30-60$ & $60-90$ & \\
\hline River levees soil & Sand & 12 & 13 & 12 & silty loam \\
& Silt & 66 & 65 & 67 & \\
& clay & 22 & 22 & 21 & \\
\hline Flood plain soil & Sand & 4 & 3 & 4 & silty clay loam \\
& Silt & 64 & 52 & 70 & \\
& clay & 32 & 45 & 26 & \\
\hline
\end{tabular}

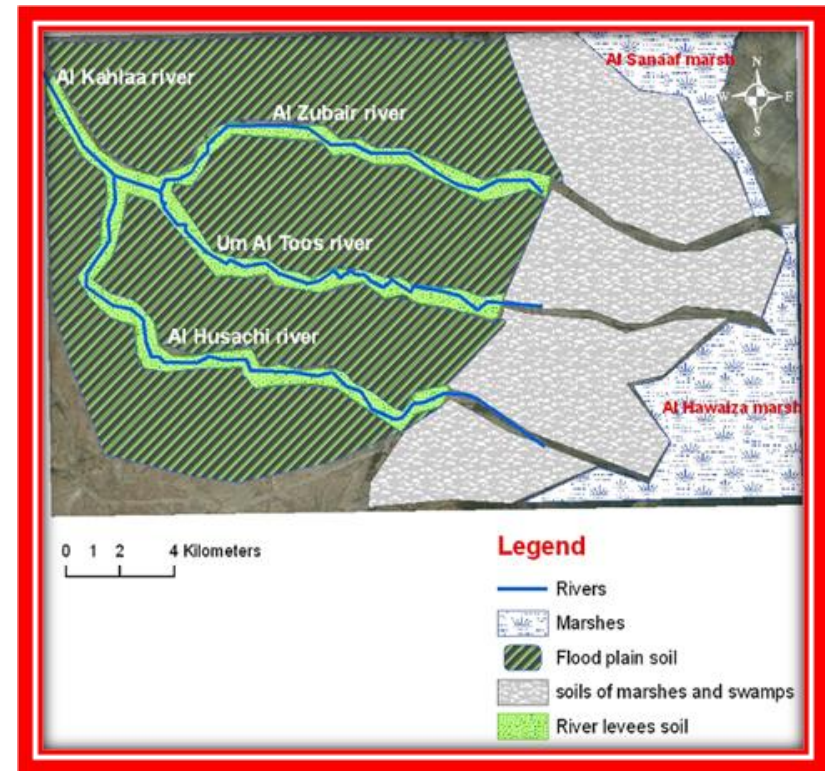

Figure (5) Types of soils in study area, (done by researcher with dependence on thesis for [4].

\section{Water resources}

Water resources include (rainwater, groundwater and surface water); the surface water represents by the main river Al-Kahlaa and its tributaries which is the only source of irrigation water for the area. The average annual rain rate is $0.6 \mathrm{~mm} /$ day for the last (30) years according to (The state board of meteorological and seismology), it cannot be relied on for cultivation.

The groundwater does not have any importance in agricultural and non-agricultural exploitation, because of the high salinity which reach 18 ds.m-1 last year (2009) in some places according to (General Commission of ground water in Maysan), this source of water is not suitable for irrigation because it harms the plant growth, has negative effect on soil properties especially in the hot summer where intense evaporation occurs, leaving salts at the soil surface. It is clear that the main water resource supplied to Al-Hawizeh marsh and relied upon in agricultural production is represented by the main river of Al-Kahlaa and its three major branches (Al-Husachi , Um- Al Toos or what is called Al-Akrah and Al-Zubair), (Figure 5).

There are existed the drainage systems with absence of natural outlets. The discharges of drainage water is towards Al- Hawizeh marsh which flow back its water into Tigris river through several canals, thus lead to a contamination in marsh and Tigris river waters.

\section{Conclusions}

It is shown that there are a serious problem existed in the drainage systems with absence of natural outlets, the discharges of drainage water is towards Al- Hawizeh marsh which flow back its water into Tigris river through several canals, increasing salinity, scare of water, miss-use of land, lack of governments efforts to promote agricultural production leads to loss of soil productivity and land degradation. There are agricultural areas surrounded by marshes, thus encouraged excess ground water builds up in recharge area (agricultural areas) to the point where lateral ground water flow occur. The ground water then emerges at the soil surface when evaporate, leaving the salts behind on the soil surface.

References

1. Al SaeedWalii M. (1971). Product of rice in province of Maysan and relation it with natural factors. Journal of Arts College in university of Basrah, 5,163. (in Arabic)

2. AzzamAlwash; Suzanne Alwash; Andrea Cattarossi. "Iraq's Marshlands - Demise and the Impending Rebirth of an Ecosystem" University of Reno, Nevada. Retrieved 7 August 2010.

3. Osaam T. Al Salaim, Soils characteristics of Maysan province, master thesis submitted to University of Basrah, College of Arts, Basrah, (1989). (in Arabic)

4. Rayaad M. Hussain, Analysis of effect some geographical factors on agricultural product in $\mathrm{Al}$ Kahlaa region, master thesis submitted to University of Basrah, College of Arts, Basrah, (1995). (in Arabic).

Offices:

(Ministry of water resources).

(The state board of meteorological and seismology)

(General Commission of ground water) 
(Marshes Recovery Center in Maysan).

(Marine Science Center in University of Basrah).

(Agriculture Directorate of Maysan, department of marshes recovery).

Internet Resources:

(http://www.afka.org).

(http://www.uobasrah.edu.iq) 